\title{
AVRUPA İNSAN HAKLARI MAHKEMESI'NIN YAPISI ve 14 NOLU PROTOKOL
}

The Structure of European Court of Human Rights and the Protocol No. 14

Yrd.Doç.Dr. Faruk BİLIR*

\section{GİRIŞ}

İnsan Hakları ve Ana Hürriyetlerini Korumaya Dair Sözleşmenin Oluşturduğu Denetim Mekanizmasının Değiştirilmesine İlişkin 14 Nolu Protokol 13 Mayıs 2004 tarihinde Sözleşmeye taraf Devletlerin imzasına açılmıştır. Protokol ile Avrupa İnsan Hakları Mahkemesi tarafından incelemeye değer bulunmayan önemsiz nitelikteki başvuruların ilk incelemelerinin daha hızlı yapılarak sonuçlandırılması, kabul edilebilirlik şartlarına başvuran kişinin önemli oranda zarar görmesi unsurunun eklenmesini öngörülmekte. Başvuruların daha az sayıda yargıç tarafından incelenebilmesine imkan sağlanması amaçlanmaktadır. Mahkeme'nin mevcut sistemine, gelen başvuruların ilk incelemesini yapmak üzere tek yargıç sistemi eklenmiş, bu görevi yapmakta olan komitelere de bazı şartlarla başvuruların esasını inceleyerek karar verebilmelerine imkan sağlanmıştır.

Protokol ile tek yargıç düzeni, yargıçların görev süreleri, komitelerin yetkileri, kabul edilebilirlik şartları, dostane çözümler, davanın incelenmesi ve kararların bağlayıcılığı ve uygulanması ile ilgili birçok yeni düzenleme getirilmektedir. Ayrıca bu düzenlemeler ile madde numaraları konusunda da birtakım değişiklikler vardır. Hiç şüphesiz yapılan bu değişiklikler denetim

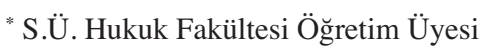


sistemini daha da etkinleştirmeye yöneliktir. Mahkemeye artan oranda başvurunun yapılması, mahkemenin artan iş yükü ve Sözleşmeye taraf ülke sayısının artması karşısında böyle bir değişiklik gereklidir ${ }^{1}$. Kaydedilen başvuru sayısı, 1999 yılında, 8400, 2000 yılında, 10482, 2001 yılında 13845, 2002 y1lında 28214, 2003 yılında 27189, 2004 yılında 32512 dir. 11 Nolu Protokolün yürürlüğe girişini izleyen üç yıl içinde Mahkemenin dava yükü daha önce görülmemiş bir hızla artmıştır. Kaydedilen başvuru sayısı \% 130 luk bir artış göstermiştir. Bu artan bir oranda devam etmektedir. 1998 yılında yapılan değişiklikten sonra mahkemeye yapılan başvuru sayısındaki artışın yanında mahkemenin verdiği karar sayısında da önemli ölçüde bir artış söz konusudur. Mahkeme, 1999 yılında 177, 2000 yılında 695, 2001 yılında 889, 2002 yılında 844, 2003 yılında 703, 2004 yılında 718 karar vermiştir ${ }^{2}$.

1998 yılında yürürlüğe giren 11 Nolu Protokol öncesi, başvurular ilk önce İnsan Hakları Avrupa Komisyonu tarafından incelenmekte, daha sonra İnsan Hakları Avrupa Mahkemesine gönderilmekteydi. Bu dönemde, Mahkemenin yanı sıra, Komisyon ve Bakanlar Komitesi'nin de yargısal yetkileri vardı. Bu düzenleme komisyonu ortadan kaldırdığ 1 gibi, Bakanlar Komitesinin yargısal işlevini de ortadan kaldırmıştır. Bu protokol öncesinde, Komisyon tarafından haklı bulunan başvurular eğer Divan önüne getirilmezse, Bakanlar Komitesi Sözleşmenin ihlal edilip edilmediğine ve eğer ihlal olduğu kanaatinde ise mağdura tazminat ödenmesine karar verebilmekteydi ${ }^{3}$. 11 Nolu

\footnotetext{
1 Mahkemede görev yapan Türk yargıç Rıza TÜRMEN, Sözleşmeye taraf ülkelerin değişmesiyle, davaların niteliğinin de değişmeye başladığını, mahkemenin yetkilerini genişletmek, farklılaşan davalara göre yeni yapılanma içine girmek istediğini ifade etmektedir. Milliyet, 11.03.2004, 14. protokolün giriş kısmında hazırlanma amacı şu şekilde ifade edilmektedir: Avrupa İnsan Hakları Mahkemesi ve Avrupa Konseyi Bakanlar Komitesi'nin iş yükünün sürekli artması karşısında, uzun dönemde denetim sisteminin etkinliğinin sağlanması ve geliştirilmesi için Sözleşme'nin belirli hükümlerinin acilen değiştirilmesi ihtiyacını göz önünde bulundurarak ve özellikle, Mahkeme'nin Avrupa'da insan haklarının korunması alanındaki üstün rolünü devam ettirebilmesinin sağlanması gereksinimini göz önünde bulundurarak hazırlanmıştır.

2 Avrupa İnsan Hakları Mahkemesi; 1955 yllından 1998 yılına kadar 143325 basvuru yapılmış, bu sayı 11 No"lu protokolden sonra (2005 yılına kadar) 198176 olmuş ve başvurular \%38 artış göstermiştir. Avrupa İnsan Hakları Mahkemesi; 1955 yılından 1998 y1lına kadar 45028 kabul edilebilirlik kararı verilmis, bu say1 11 No'lu protokolden sonra (2005 yılına kadar) 120642 olmuş ve kabul edilebilirlik kararları \%167 artış göstermiştir. Avrupa İnsan Hakları Mahkemesi; 1955 yılından 1998 yılına kadar 37561 karar verilmiş, bu say1 11 No'lu protokolden sonra (2005 yılına kadar) 79497 olmuş ve kararlar \%111 artış göstermiştir. Avrupa İnsan Hakları Mahkemesi; 1955 yılından 1998 yılına kadar verilen kararlardan 32617'si reddedilmiştir, bu sayı 11 No'lu protokolden sonra (2005 y1lına kadar) 74775 olmus ve kararlar \%129 artıs göstermiștir. Avrupa İnsan Hakları Mahkemesi; 1955 yılından 1998 yılına kadar verilen kararlardan 4923'ü kabul edilmiştir, bu sayı 11 No'lu Protokolden sonra (2005 y1lına kadar) 4717 olmus ve kabul edilen kararlarda \%0,4 azalma olmuştur. Avrupa İnsan Hakları Mahkemesi; 1955 yılından 1998 yılına kadar verilen 837 nihai karar, bu sayı 11 No'lu protokolden sonra (2005 yılına kadar) 4026 olmuş ve kararlar \%381 artışöstermiştir,http://www.echr.coe.int/ECHR/EN/Header/Reports+and+Statistics/S tatistics/ Statistical+Tables/29.11.2005

BIÇAK, Vahit," Yeni Yapısıyla Avrupa İnsan Hakları Mahkemesi",
} 
Protokol $^{4}$, Sözleşmenin denetim organı olarak tam zamanlı çalışan tek mahkeme sistemini benimsemiştir. Ancak yeni mahkemenin de kendi içerisinde bir yapılanması söz konusudur. Buna göre üç yargıçlı Komiteler, yedi yargıçlı Daireler ve on yedi yargıçlı Büyük Daire şeklinde toplanılır. Mahkeme'nin Daireleri belirli bir süre için Komiteleri oluşturmaktadır.

Bir başvurunun kabul edilebilirliği hususunda ilk incelemeyi Komite yapmaktadır. Sözleşmenin 28. maddesine göre bir Komite kişisel başvurunun daha fazla incelemeyi gerektirmediği hallerde oybirliği ile kabul edilemezliğine veya kayıttan düşürülmesine kesin olarak karar verebilir. 28. madde çerçevesinde karar verilmediği takdirde bir daire yapılan kişisel başvuruların kabul edilebilirliği ve esası hakkında karar verir. 29. maddenin ikinci fıkrasına göre devlet başvurularının kabul edilebilirliği ve esası hakkında karar verecek olan da bir dairedir. Ancak, "Daire önünde görülen dava, işbu Sözleşmenin ve protokollerinin yorumu konusunda ciddi sorunlar doğuruyorsa ya da sorunun çözümü Mahkeme tarafından önceden verilmiş bir karar ile çelişkili olacak ise, Daire, hüküm vermediği süre içerisinde, taraflar itiraz etmedikçe, yargı yetkisinden Büyük Daire lehine vazgeçebilir. (AİHS md. 30).

Sözleşmenin 35. maddesinde, başvurunun kabul edilebilirlik şartları düzenlenmiştir. $\mathrm{Bu}$ maddede hem bireysel hem de Devlet başvuruları için ortak iki şart aranmaktadır. Bu şartlardan birincisi iç hukuk yollarının tüketilmiş olması, diğeri ise iç hukuktaki nihai karardan itibaren altı ay içerisinde başvurunun yapılmış olmasıdır.

Avrupa İnsan Hakları Mahkemesi'nin daha etkin bir şekilde işleyişini sağlamayı öngören 14 Nolu Protokol henüz yürürlüğe girmemiştir. Bu protokol, Sözleşme'nin tüm Taraflarının Protokol ile bağlanma rızalarını bildirdikleri tarihten sonra başlayan üç aylık sürenin bitimini takip eden ayın birinci günü yürürlüğe girecektir (14 Nolu Protokol md. 19) $)^{5}$. Bu Protokol'ün yürürlüğe girdiği tarihten itibaren hükümleri, Avrupa İnsan Hakları Mahkemesi'nde görülmekte olan bütün başvurular ile icrası Bakanlar Komitesi tarafından denetlenen bütün kararlara uygulanacaktır (14 Nolu Protokol md. 20).

http://www.geocities.com/vbicak/art2. htm.17.11.2005.

${ }^{4} 11$ Nolu Protokol ile Avrupa İnsan Hakları Mahkemesinin oluşumunda, yetki ve yargılama usulünde çok önemli değişiklikler yapılmıştır. Bu değişiklikler, "Avrupa Konseyi üye sayısındaki artış ve üyelik başvurularındaki yoğun talep nedeniyle hakların korunmasındaki etkinliği sürdürmek ve geliştirmek amacıyla denetim mekanizmasını yeniden yapılandırmak"' şeklinde ifade edilmiştir.

${ }^{5}$ 06.03. 2006 tarih itibariyle, 14 Nolu Protokol, 45 ülke tarafından imzalanmış, 27 ülke tarafından da onaylanmıştır. Protokolü onaylayan ülkeler şunlardır: Ermenistan, Bulgaristan, Kıbrıs, Danimarka, Gürcistan, Yunanistan, İrlanda, Lihtenştayn, Litvanya, Malta, Moldova, Norveç, Romanya, Sırbistan ve Karada ̆̆, Slovakya, Slovenya, İsveç, Eski Yugoslavya Makedonya Cumhuriyeti, İngiltere, Macaristan, Arnavutluk, Avusturya, Estonya, Monaco, San Marino ve Hırvatistan'dır. Türkiye 14 Nolu Protokolü 6.10.2004 tarihinde imzalamış, ancak henüz onaylamamıştır. http://conventions.coe.int/Treaty/Commun/ ChercheSig.asp? $\mathrm{NT}=194 \& \mathrm{CM}=1 \& \mathrm{DF}=\& \mathrm{CL}=\mathrm{ENG}$. 
Biz bu çalışmada, genel olarak 14 Nolu Protokol ile getirilen değişiklikler üzerinde duracağız. Ayrıca bu çalışmada, Mahkemenin mevcut yapısı ve yargılama süreci, yeni getirilen düzenlemelerle karşılaştırmalı olarak incelenecektir.

\section{1- Yargıçların Görev Süreleri ve Görevden Alınma}

Avrupa İnsan Hakları Sözleşmesinin 23. maddesinde yeni yapılan düzenleme ile yargıçların görev süreleri 9 yıla çıkarılmaktadır. Tekrar seçilmeleri de mümkün değildir (14 Nolu Protokol md. 2) ${ }^{6}$. Önceki düzenleme yargıçların görev sürelerini 6 yıl olarak öngörmüştü ve tekrar seçilmeleri de mümkündü. Bu düzenleme ile yargıçların bir kez olmak şartıyla daha uzun süre görev yapma imkanı sağlanmıştır. Bu düzenleme ile tekrar 11 Nolu protokol öncesindeki görev sürelerine dönülmüştür. Yargıçların görev sürelerini doldurduktan sonra seçilememelerine ilişkin düzenlemenin olumlu ve olumsuz yönünün olduğu söylenebilir. Yargıçların tekrar seçilememelerinin olumsuz yönü, tecrübeli hakimlerin tecrübelerini yenileriyle paylaşması ve içtihatlarda sürekliliğin sağlanması imkanın büyük ölçüde zayıflayacağıdır. Bu durumun olumlu yönünü de, tekrar seçilebilme ihtimali halinde hakimin kendi ülkesi resmi makamlarına karşı bağımlılığında önemli bir etken olacağı dolayısıyla böyle bir ihtimalin olmaması halinde yargıcın bağımsız ve tarafsızlığına önemli ölçüde korunmasidir ${ }^{7}$.

Yeni düzenlemede de yargıcın görev süreleri 70 yaşında sona ermektedir. Yargıçlar, yerlerine başkası seçilinceye kadar görevlerini sürdüreceklerdir (14 Nolu Protokol md. 2). Yerlerine başkası seçildikten sonra da kendilerine havale edilmiş olan davalara bakmaya devam edecekler. Yeni düzenleme yargıçlarda görev için aranan şartlarda herhangi bir değişiklik getirmemiştir. Buna göre; yargıçlar üstün ahlaki vasıflara ve yüksek bir hukuki göreve atanmak için gerekli niteliklere sahip veya ehliyetleriyle tanınmış hukukçu olmalıdırlar. Yargıçlar Mahkemeye kendi adlarına katılırlar. Görev süreleri içerisinde yargıçlar, bağımsızlıkları, tarafsızlıkları ve daimi görevin gerekleri ile bağdaşmayan herhangi bir görev üstlenemezler (AİHS, md.21).

Yargıçlar, Avrupa İnsan Hakları Sözleşmesine taraf ülkeler için, o ülke tarafından gösterilen ve üç aday içeren bir liste üzerinden Avrupa Konseyi Parlamenterler Meclisi tarafından oy çokluğu ile seçilirler (AİHS, md 22/1) ${ }^{8}$.

${ }^{6}$ ÜLGEN, Celal, Avrupa İnsan Hakları Mahkemesi'ne Bireysel Başvuru Yöntemi, İstanbul 2006, s. 13.

${ }^{7}$ DÖNER, Ayhan, İnsan Haklarının Uluslar arası Alanda Korunması, Ankara 2003, s. 182183

${ }^{8}$ Sözleşmede yer almamasına rağmen, alınan bir idari kararla üye Devletler tarafından gösterilen yargıç adayları Parlamenter Meclisi üyelerinden oluşan bir komisyon tarafından bir "mülakata" tabi tutulmaktadırlar. GÖLCÜKLÜ, Feyyaz, "11 Nolu Protokol'den Sonra 
Sözleşmenin 22. maddesinin ikinci fıkrasında yer alan "Yeni Yüksek Sözleşmeci Tarafların bu Sözleşme'ye katılmaları halinde Mahkeme'yi tamamlamak ve boşalan üyelikleri doldurmak için aynı usul izlenir" hükmü 14 nolu protokol ile kaldırılmıştır (14 Nolu Protokol md. 2). Avrupa İnsan Hakları Mahkemesi, Avrupa İnsan Hakları Sözleşmesine taraf sayısına eşit sayıda yargıçtan oluşur. Aynı tabiyeti taşıyan yargıçların sayısı yönünden hiçbir sınırlama mevcut değildir'. Ayrıca yargıçların atandıkları ülkenin vatandaşı olma şartı yoktur. Sözleşmeci Devlet başka bir ülke vatandaşını da aday gösterebililin ${ }^{10}$ Yargıçlar, Mahkeme Başkanı, başkan yardımcıları ve bölüm başkanlarından sonra, seçilme tarihlerine göre kıdem almaktadırlar ${ }^{11}$. 05.12.2005 tarihi itibariyle Mahkeme $45^{12}$ yargıçtan oluşmaktadır ${ }^{13}$.

Yargıçların, özgeçmişlerinin standartlaştırılması amacı ile Mahkeme, yargıç adaylarına, bir model özgeçmiş geliştirilmesine karar vermiştir. 1082 sayılı karar ile adayların özgeçmişlerindeki bilgileri sistematik olarak ve hatta benzer yapıda sunmalarının, adaylar arasında mukayeseyi kolaylaştıracağı vurgulanarak, resmi bir özgeçmiş şekli oluşturulmuştur ${ }^{14}$.

Sözleşmede ilk seçilen yargıçlardan yarısının görev süreleri üç yıl olarak kabul edilmişti. Böylece her üç yılda yargıçların yarısı yenilenebilmekteydi. 14 Nolu Protokol yargıçların üç yılda yenilenmeye ilişkin düzenlemeye de son vermektedir. Bu düzenleme Mahkemenin tamamen yenilenmesinden kaçınmak için getirilmişti ${ }^{15}$. Bu Protokol'ün yürürlüğe girdiği tarihte görevlerinin birinci döneminde olan yargıçların görev süreleri kendiliğinden toplam dokuz yılı tamamlayacak şekilde uzatılacak, diğer yargıçlar, kendiliğinden iki yıl süreyle uzatılan görev

Avrupa İnsan Hakları Sözleşmesi”, Yeni Türkiye (İnsan Hakları Özel Sayısı II), TemmuzA ğustos 1998, Yı1:4, Sayı:22, s. 1275; BIÇAK, Vahit, "Yeni Yapısıyla Avrupa İnsan Haklar1 Mahkemesi" http://www.geocities.com/vbicak/art2. htm.17.11.2005.

${ }^{9}$ İtalya, San Marino ve Malta adına görev yapan üç İtalyan yargıç bulunmaktadır.

${ }^{10}$ YAMAN, Hamza, Avrupa İnsan Hakları Mahkemesine Müracaat Usul ve Esasları, Ankara 2004, s. 163. Nitekim, Liechtenstein adına İsviçre'li bir yargıç görev yapmaktadır. http://www.echr.coe.int/ ECHR/EN/Header/The+Court/The+Court/Composition+of+the+ Plenary+Court/(13.02.2006)

${ }^{11}$ ERGÜL, Ergin, Avrupa İnsan Hakları Mahkemesi ve Uygulaması, Ankara 2004, s. 15.

${ }^{12} \mathrm{http} / / / \mathrm{www}$. echr.coe.int/ECHR/EN/Header/The+Court/The+Court/Composition+of+the+Ple nary+Court/ (13.02.2006) Monaco adına henüz yargıç seçilmedi.

${ }^{13}$ Mahkeme Başkanlığı İsviçre'li yargıç Lozius Wildhaber, başkan yardımcılıkları Fransız yargıç Jean Paul Costa ve Yunanistanlı yargıç Christos Rozakis tarafından yürütülmektedir. İsviçreli hakim Lucius Caflish, Lihtenştayn adına seçilmiştir. Mahkemede görev yapan Türk yargıç Rıza Türmen'dir. Türk yargıcın Daire başkanlığı veya Daire başkan yardımcılığı gibi herhangi bir idari görevi bulunmamaktadır. Rıza Türmen 2. Section'la ilişkilendirilmiştir. 2. Section'da Türkiye ile birlikte Yunanistan, Macaristan, Portekiz, Çek Cumhuriyeti, Ukkrayna, Gürcistan, İsveç, San Marino, Litvanya ve Sirbistan- Karadağ yer almaktadır.

http://www.echr.coe.int/ECHR/EN/Header/The+Court/The+Court/Composition+of+the+Se ctions/.13.02.2006

14 BIÇAK, Vahit, "Yeni Yapısıyla Avrupa İnsan Hakları Mahkemesi", http://www. geocities.com/vbicak/art2. htm.17.11.2005.

${ }^{15}$ BIÇAK, Vahit, "Yeni Yapısıyla Avrupa İnsan Hakları Mahkemesi", http://www.geocities. com/vbicak/art2. htm.17.11.2005. 
sürelerini tamamlayacaklardır (14 Nolu Protokol md. 21).

Sözleşmenin görevden alma ile ilgili 24. maddesindeki düzenleme, 23. maddeye eklenmiştir. Bu düzenlemeye göre, hiçbir yargıç, diğer yargıçlar tarafından gerekli koşulları yerine getirmediğine üçte iki çoğunluk ile karar verilmedikçe, görevden alınmayacaktır (14 Nolu Protokol md. 2).

\section{2- Yazı İşleri Birimi ve Raportörler}

Sözleşme'nin 25'inci maddesi, madde 24 olmuştur ve metni şu şekilde değiştirilmiştir: "Mahkeme'de, görevleri ve kuruluşu Mahkeme içtüzüğüünde belirlenen bir Yazı İşleri Müdürlüğü bulunur. Tek yargıç düzeninde kurulduğunda mahkemeye, Mahkeme Başkanı'nın yetkisi altında görev yapan raportörler tarafından yardım edilir. Raportörler Mahkeme'nin Yazı İşleri'nin bir parçasını oluşturur."

Mahkeme İçtüzüğüne göre, Mahkeme Yazı İşleri Müdürü, Mahkeme genel kurulu tarafından seçilir. Adaylar, yüksek ahlaki niteliklere ve hukuk, idare ve dilbilgisine sahip ve makamın gerektirdiği görevleri yürütebilecek gerekli tecrübeye sahip olmalıdır. Yazı İşleri Müdürü ${ }^{16}$, beş yıl için seçilir ve yeniden seçilebilir (İçtüzük md.15). Yazı İşleri, Mahkeme tarafında kurulan Bölümlere eşit sayıda Bölüm, Yazı İşlerinden ve Mahkeme tarafından ihtiyaç duyulan hukuki ve idari hizmetleri sağlayacak gerekli birimlerden meydana gelir (İçtüzük md.18/1).

Sözleşme'nin 33.maddesine göre yapılan bir Devlet başvurusunda, davayı görmek üzere oluşturulan Daire, bir veya birden fazla yargıcı, raportör olarak görevlendirir. Raportör veya raportörler, ilgili Sözleşmeci Devletlerin yazılı cevaplarını aldıktan sonra, gerektiği takdirde kabul edilebilirlik hakkında bir rapor sunarlar. Yapılan bir başvurunun kabul edilebilir olduğu açıklandıktan sonra, Raportör yargıç veya yargıçlar bu raporları, taslakları ve Dairenin görevini yerine getirmesi sırasında yardımcı olacak diğer belgeleri Daireye sunarlar (İçtüzük md.48).

Sözleşme'nin 34.maddesine göre, davayı görmesi için kendisine havale edilen Bölümün Başkanı, başvuruyu inceleyecek olan bir Raportör Yargıç görevlendirir. Başvurunun ilk incelemesinden sonra, raportör bunun üç üyeli

\footnotetext{
16 İçtüzüğe göre, Yazı işleri Müdürünün görevleri şunlardır: 1- Yazı İşleri Müdürü, Mahkeme'nin görevlerini yerine getirmesinde yardımcı olur ve Mahkeme Başkanının denetiminde Yazı işlerinin örgütlenmesinden ve faaliyetlerinden sorumludur. 2- Yazı İşleri Müdürü, Mahkeme arşivini tutar. Mahkeme önüne getirilen veya getirilecek olan bütün davalarda, Mahkeme'den yapılan veya Mahkeme'ye gönderilen bütün yazışmalar ve bildirimler Yazı İşleri Müdürü kanalıyla yürütülür. 3- Yazı İşleri Müdürü, bu makama verilen takdir yetkisine bağlı olarak, Mahkeme'nin çalışmasıyla ilgili bilgi taleplerini ve özellikle basından gelen istekleri karşılar. 4- Yazı işlerinin çalıșması, Yazı İşleri Müdürü tarafından hazırlanan ve Mahkeme Başkanı tarafından onaylanan genel talimatlarla düzenlenir (İçtüzük md. 17).
} 
bir komite tarafından mı, yoksa Daire tarafından mı inceleneceğine karar verir (İçtüzük md.49).

\section{3- Tek Yargıçlı Düzen, Komiteler, Daireler ve Büyük Daire}

Sözleşmenin 27. maddesi, 26. maddesi olmuştur. Bu yeni düzenlemeye göre, Mahkeme'nin yapılanması, tek yargıçlı düzen, 3 yargıçlı Komiteler, yedi yargıçlı Daireler ve 17 yargıçlı Büyük Daire şekline dönüşsürülmüştür. Bu yapılanma ile tek yargıçlı bir düzen, Mahkeme'nin yapısına eklenmiştir. Davanın tek yargıç tarafından görüldüğ̈̈i durumlarda, yargıç seçilmiş olduğu Devlet ile ilgili hiçbir başvuruyu inceleyemeyecektir. Yine bu maddede yapılan düzenlemeye göre, Mahkeme Genel Kurulunun talep etmesi üzerine, Bakanlar Komitesi oybirliğiyle alınan karar ile ve belirli bir süre için Dairelerdeki yargıç sayısını beşe düşürebilir. Bu düzenleme ile, hakimlerin iş yükünün azaltılması ${ }^{17}$ ve dairelerin daha hızlı bir şekilde karar verebilmelerinin amaçlandığını söyleyebiliriz. Başvuruya konu olan Yüksek Âkit Devlet adına seçilmiş yargıç, Daire ve Büyük Daire'de re'sen yer alır; bu yargıcın yokluğunda veya katılması mümkün olmayan durumlarda, anılan devletin önceden sunacağ 1 listeden Mahkeme Başkanınca seçilen bir kişi yargıç sıfatıyla yer alır (14 Nolu Protokol md. 6).

Büyük Daire'de, ayrıca Mahkeme Başkanı, Başkan Yardımcıları, Daire Başkanları ve Mahkeme İçtüzüğüne göre seçilecek diğer yargıçlarda bulunur. Bir başvuru, Büyük Daire'ye sevk edildiğinde, Daire Başkanı ve ilgili Yüksek Âkit Taraf adına seçilmiş yargıç haricinde, bu kararı vermiş olan Daire yargıçları Büyük Daire'de yer alamazlar (14 Nolu Protokol md. $6)$.

Mahkeme İçtüzüğüne göre, Daireler (Bölümler) Mahkeme Başkanının hazırladığı bir öneri üzerine Mahkeme genel kurulu tarafından üç yıllık bir süre için kurulur. En az dört Bölüm bulunur. Her yargıç bir Bölümün üyesidir. Bölümler, coğrafya ve cinsiyet açısından dengeli ve Sözleşmeci Devletler arasındaki değişik hukuk sistemlerini yansıtacak şekilde oluşturulur (İçtüzük md. 25) ${ }^{18}$. Mahkeme'nin önüne getirilen davaların görülmesi için yedi yargıçlı Daireler, Bölümlerin içinden oluşturulur. Her bir dava için Dairede, Bölüm Başkanı ve ilgili Sözleşmeci Devlet nezdinde seçilmiş yargıç yer alır. İlgili Sözleşmeci Devlet nezdinde seçilmiş yargıç, başvurunun gönderildiği Bölümün üyesi değilse, bu yargıç Dairede re'sen yer alır. Dairenin diğer üyeleri, Bölüm Başkanı tarafından ilgili Bölümün üyeleri arasından rotasyon usulüyle görevlendirilir. $\mathrm{Bu}$ surette görevlendirilmemiş olan Bölüm üyeleri, bu davada yedek yargıçlar olarak yer alır (İçtüzük md. 26).

${ }^{17}$ AYKAÇ, Alper Can, "14. Protokol ile Avrupa İnsan Hakları Sözleşmesi'nin Değişen Denetim Mekanizması", Hukuk Gündemi, Sayı:3, Aralık 2005, s. 86.

${ }^{18}$ Mahkemenin İçtüzüğü için bkz. AKILLIOĞLU, Tekin, Avrupa İnsan Hakları Sözleşmesi, Avrupa İnsan Hakları Mahkemesi İçtüzüğüi Başvuru Bilgileri, Ankara 2002. 
Dairelerin, başvuruların kabul edilebilirlik incelemesini yapma ve davanın esasını inceleme yetkileri vardır. Yani daireler komitelerin kabul edilemezlik kararı vermediği bireysel başvurular ile Devlet başvurularını kabul edilebilirlik ve esas hakkında inceleyip karara bağlamakla görevlidirler ${ }^{19}$. Dairelerin kararları kesindir. Ancak bazı durumlarda, davanın esasını karara bağlama yetkisi Büyük Daireye verilmiştir. Daire önünde görülen dava, Sözleşmenin ve protokollerinin yorumu konusunda ciddi sorunlar doğuruyorsa ya da sorunun çözümü Mahkeme tarafından önceden verilmiş bir karar ile çelişkili olacak ise, Daire, hüküm vermediği süre içerisinde, taraflar itiraz etmedikçe, yargı yetkisinden Büyük Daire lehine vazgeçebilir (AİHS md. 30). Ayrıca, Daire kararının verildiği tarihten itibaren üç ay içerisinde, dava taraflarından her biri, istisnai durumlarda, davanın Büyük Daireye gönderilmesini isteyebilir. Büyük Daire bünyesinde beş yargıçtan oluşan bir kurul, istemi kabul ederse, Büyük Daire bir hüküm ile davayı sonuçlandırır (AİHS md. 43). Bir dairenin kararı ise aşağıdaki durumlarda kesinleşir (AİHS md. 44):

a) Taraflar davanın Büyük Daire'ye gönderilmesini istemediklerini beyan ederlerse (temyiz hakkından feragat).

b) Karardan itibaren üç ay içerisinde davanın Büyük Daire'ye gönderilmesi istenmezse.

c) Büyük Daire, istemi reddederse.

Hükümler ve başvuruların kabul edilebilirliğine veya kabul edilemezliğine ilişkin kararlar gerekçelidir. Hüküm, yargıçların oybirliğini içermediği takdirde her yargıç kendi ayrı görüşünü belirtmek hakkına sahiptir (AİHS md. 45). Kararlar, oylamada hazır olan yargıçların çoğunluğu ile alınır. Eşitlik halinde oylama tekrar edilir ve yine eşitlik çıkması halinde başkanın bulunduğu taraf üstün kabul edilir (İçtüzük md.23).

\section{4- Tek Yargıçların Yetkileri}

Tek Yargıcın yetkileri yeni eklenen 27. maddede sayılmıştır. Yapılan düzenlemeye göre, tek yargıçlar yapılan başvuruların ön incelemesini (kabul edilebilirlik) yapacaktır. Tek yargıçlar yeniden incelemeye gerek olmaksızın karar alınabilecek hallerde başvuruyu kabul edilemez bulabilir veya kayıttan düşürebilir. Tek yargıcın vermiş olduğu kararlar kesindir. Tek yargıç bir başvuru hakkında kabul edilmezlik kararı vermez veya başvurunun kayıttan düşürülmesine karar vermez ise, başvuruyu incelenmesi için bir komiteye veya bir daireye iletecektir (14 Nolu Protokol md. 7). Yapılan bu düzenleme

${ }^{19}$ ÖZDEK, Yasemin, Avrupa İnsan Hakları Hukuku ve Türkiye, Ankara 2004, s. 47. 
ile, komitelerin yaptığı görevler tek yargıca da verilmiştir. Mahkeme tarafından incelenmeye değer bulunmayan ve büyük bir zaman kaybına yol açan önemsiz nitelikteki başvuruların ilk incelemeleri daha hızlı yapılabilmesi için tek yargıç tarafından incelenebilmesi öngörülmüştür. Çok sayıda başvuru yapılması karşısında bu düzenleme ile eleme/ayıklama tedbirleri getirilmiştir. Buna göre eskiden üç üyeli filtre komitesinin yaptı̆̆ 1 bu işlem tek yargıç üye tarafından yapılabilecektir ${ }^{20}$. Bu düzenleme Mahkeme tarafından incelenmeye değer bulunmayan ve büyük bir zaman kaybına yol açan önemsiz nitelikteki başvuruların ilk incelemelerinin tek yargıca verilmesi konusunda yerinde bir düzenlemedir. Ancak bu düzenleme ile Mahkemenin yapılanmasında önemli bir yeri olan kurul halinde karar verme konusunda, kabul edilebilirlik konusunda farklı bir yönteme gidildiğini söylemek mümkündür. Bu düzenleme yargıçların iş yükünün artmasına neden olacaktır. Ayrıca, tek yargıcın bu şekilde bir yetki ile donatılması önemli bir yeniliktir. Bu düzenlemenin amacına ulaşabilmesi için hiç şüphesiz başvuru dosyasının eksiksiz bir şekilde hazırlanması büyük önem taşıyacaktır ${ }^{21}$.

14 Nolu Protokole göre, Tek yargıç düzeni oluşturulduğunda, yargıç seçilmiş bulunduğu Devlet ile ilgili başvuruları inceleyemez (14 Nolu Protokol md. 6). Bu düzenlemenin başvuruda bulunan kişiler açısından güvence teşkil ettiğini söyleyebiliriz. Şüphesiz bu hüküm yargıçların seçilmiş bulunduğu Devlet ile ilgili başvurular konusunda, baskı altında kalmamaları ve Mahkemenin tarafsızlığının sağlanması açısından olumlu bir düzenlemedir. Tek yargıç oluşumunda yargıçların ağır iş yükü altında kalmamaları için, Mahkeme'ye, Mahkeme Başkanı'nın yetkisi altında görev yapan raportörler tarafından yardım edileceği düzenlenmiştir (14 Nolu Protokol md. 4).

\section{5- Komitelerin Yetkileri}

Komitelerin başvurular konusunda kabul edilebilirlik veya kayıttan düşürme ile ilgili görevleri de devam etmektedir. Bilindiği gibi, Komiteler, yapılan başvurular açısından bir filtre görevi görmektedir. Komiteler açık ve net şartların varlığı halinde, bireysel başvurular hakkında oybirliğiyle kabul edilemezlik kararı verirler ${ }^{22}$. Ayrıca getirilen düzenlemelerle, komitelere yargılama yapma yetkisi de verilmiştir. Dolayısıyla yapılan düzenleme ile komitelerin yetkileri artırılmıştır. Komitelerin yetkileri başlıklı 28. maddeye göre, yeniden incelemeye gerek olmaksızın karar alınabilecek hallerde,

${ }^{20}$ AKILLIOĞLU, Tekin, “İnsan Hakları Sorunu Deyimimin Anlamı ve İşlevi”, http://www. egm.gov.tr/apk/dergi/42/makale/Tekin_AKILLIOGLU.htm.15.11.2005.

${ }^{21}$ CENGIZ, Serkan, "14 Nolu Protokol İle Avrupa İnsan Hakları Sözleşmesi'ne Getirilecek Olan Değişiklikler" http://www.turkhukuksitesi.com/makale_185.htm. 03.12.2005.

${ }^{22}$ SIMMONS, Alan, İnsan Hakları Avrupa Mahkemesine Başvuru, (Çev. Defne Orhun), İstanbul 2005, 23. 
komite oybirliğiyle, başvurunun kabul edilmezliğine veya kayıttan düşürülmesine karar verebilir. Ayrıca davanın temelini teşkil eden sorun, sözleşme veya Protokollerin uygulanması veya yorumlanması ile ilgili olup, zaten Mahkeme'nin yerleşmiş içtihadına ilişkin ise, davayı kabul edebilir bulabilir ve aynı anda davanın esasına ilisskin karar verebilir. Bu kararlar kesindir (14 Nolu protokol md. 8). Ancak komitenin bu kararları oybirliğiyle alması gerekir. Eğer komite bu kararları oybirliğiyle alamazsa, bu durumda kabul edilebilirlik kararı ve esas hakkındaki karar bir daire tarafından verilecektir. Kabul edilebilirlik kararı bir daire tarafından ayrı olarak ta verilebilecektir (14 Nolu protokol md. 9). Devlet başvurularında ise, ancak istisnai hallerde bir daire, kabul edilebilirlik kararını ayrı olarak verebilecektir. Bu düzenlemelerle komitelere davanın esası hakkında karar verme yetkisi de tanınmaktadır. Ancak bunun için, davanın temelini teşkil eden sorun, sözleşme veya Protokollerin uygulanması veya yorumlanması ile ilgili olmalı ve Mahkeme'nin yerleşmiş içtihadına ilişkin olmalıdır. Bu düzenleme ile komitelerin esastan karara bağladığı başvurular hakkında, daire veya Büyük Daireye müracaat imkanı yoktur. Ancak, komitelerin bu yetkilerinin, davanın temelini teşkil eden sorunun, sözleşme veya Protokollerin uygulanması veya yorumlanması ile ilgili ve Mahkeme'nin yerleşmiş içtihadına ilişkin olduğunu kabul edersek, bunun bir sakınca doğurmayacağını söyleyebiliriz. Aksine, başvurunun Mahkemenin yerleşmiş içtihatlarına ilişkin olması halinde, başvuru hakkındaki kararın kısa bir zaman dilimi içinde verilebileceğini söyleyebiliriz ${ }^{23}$. Bu düzenlemelerle başvuruların daha hızlı bir şekilde sonuçlandırılması amaçlanmaktadır. Çünkü sözleşmenin uygulanmasına ilişkin Mahkemenin verdiği kararlar sonucunda çeşitli konulara bir içtihat oluşmuştur. Dolayısıyla getirilen düzenlemeler ile, benzer başvurular ve daha önce Mahkeme tarafından çözüme kavuşturulmuş başvurular bakımından hızlı bir denetim sağlanmaya çalışılmaktadır.

Yine bu maddeye eklenen bir hükme göre, Sözleşmeye taraf Devlet adına seçilmiş yargıç komite üyesi değilse, komite, davanın her aşamasında o yargıcı, komitenin üyelerinden birinin yerine geçmeye davet edebilir (14 Nolu protokol md. 8).

\section{6- Kabul Edilebilirlik Şartları}

Yapılan önemli değişikliklerden birisi de sözleşmenin 35. maddesinde yapılan değişikliktir. Sözleşmenin 35. maddesine göre, Uluslararası Hukukun genel olarak kabul edilen prensiplerine göre, ancak iç hukuk yollarının tüketilmesinden sonra ve kesin karardan itibaren altı aylık süre içinde Mahkeme'ye başvurulabilir. Bireysel başvuru hakkından, gerçek

${ }^{23}$ CENGİZ, Serkan, "14 Nolu Protokol İle Avrupa İnsan Hakları Sözleşmesi'ne Getirilecek Olan Değişiklikler" http://www.turkhukuksitesi.com/makale_185.htm. 03.12.2005. 
kişiler, kişi toplulukları, hükümet dışı topluluklar ve tüzel kişiler yararlanabilirler. Mahkeme, başvuru imzasız ise veya başvuru Mahkeme tarafından daha önce incelenmiş veya uluslararası diğer bir soruşturma veya çözüm merciine sunulmuş başka bir başvurunun konusuyla esas itibariyle aynı ise ve yeni olaylar içermiyorsa kişisel başvuruyu kabul etmez ${ }^{24}$. Kabul edilebilirlik şartlarının düzenlendiği 35. maddenin 3. fikrasında 14 Nolu Protokolle yapılan değişiklikle, başvurunun Sözleşme veya ilgili Protokol hükümleri dışında kalması, açıkça dayanaktan yoksun olması veya bireysel başvuru hakkının suiistimali mahiyetinde olması durumunda başvuru hakkında kabul edilemezlik kararı verilir. Yine yapılan bu değişiklikle Sözleşme ve Protokollerde belirtilen insan haklarına saygı ilkesi gereğince başvurunun esası hakkında incelemeye gerek bulunması ve başvuruya konu olayın iç hukuk mahkemesince yeterince incelenmemiş olması durumları hariç olmak üzere, başvuranın önemli mağduriyetinin bulunmaması durumunda başvuru kabul edilemez bulunacaktır (14 Nolu Protokol md. 12). $\mathrm{Bu}$ değişiklikle kabul edilebilirlik şartları arasına başvuran kişinin ehemmiyetli bir dezavantaja uğrama (önemli bir mağduriyetinin bulunması ya da dikkate değer bir zarara uğramış olma) kriteri eklenmiştir. Yani, başvuran kişi dikkate değer bir zarara uğramış olması gerekir. Eğer başvuran kişinin önemli bir mağduriyeti yok ise bu durumda başvuru hakkında kabul edilemezlik kararı verilecektir ${ }^{25}$. Ancak, Sözleşme ve protokollerde belirtilen insan haklarına saygı ilkesi gereğince başvurunun esası hakkında incelemeye gerek bulunması ve başvuruya konu olayın iç hukuk mahkemesince yeterince incelenmemiş olması durumlarında başvuran kişinin önemli bir mağduriyetin bulunması şartı aranmayacaktır. Şüphesiz bu önemli bir değişikliktir. Yeni değişikliğin hem Mahkeme'nin hem de bireylerin lehine olduğunu söylemek mümkündür. Mahkeme artık gerçek manada haksızlığa uğrayanların davalarına bakabilecek ve bunları daha iyi inceleyecektir ${ }^{26}$. Bu değişikliğin yürürlüğe girmesiyle birlikte, bireysel başvurular bakımından sözleşmenin ihlal edilmesi ve başvurucunun bu ihlal nedeniyle mağduriyetinin bulunması gerekir. Başka bir ifadeyle sözleşmenin ihlali ile

${ }^{24}$ Sözleşmenin 35. maddesinin 1. ve 2. fikralarında düzenlenen şartlar şunlardır: 1-Başvuruda bulunanın kimliği belli olmalıdır, 2- Başvuru daha önce komisyonca incelenmiş bir başvuru ile aynı olmamalıdır, 3- Aynı konuda daha önce başka bir uluslararası yere başvurulmamış olması, 4- Başvurunun, sözlessme ile bağdaşır nitelikte olması, 5- Başvurunun açıkça temelden yoksun olmaması, 6- Başvuru hakkının kötüye kullanılmaması. DEMİREL, Naim, Avrupa İnsan Hakları Sözleşmesi Çerçevesinde Yapılan Bireysel Başvurular İçin Gerekli Şartlar, http://www.dicle.edu.tr/dictur/suryayin/khuka/avrupainsanhaklari.htm 29.11.2005.

${ }^{25}$ Protokolde yer alan AİHM'ne müracaat için "ehemmiyetli bir dezavantaja uğrama" şartının, gereksiz başvuruları engelleyeceğini söyleyen Bahri Öztürk, bu değişikliklerle ỉlgili şu görüşlere yer vermiş̧ir: “Yeni uygulamayla AİHM'nin başvuru davalarına daha çok önem vereceğini, Dezavantaja uğramanın kișinin önemli bir haksızlığa uğraması demek olduğunu, yeni uygulamanın hem AİHM, hem de bireylerin lehine olduğu, Mahkeme artık gerçek manada haksızlığa uğrayanların davalarına bakacak. Bunları daha iyi inceleyecek. Bu noktada devletin işi kolaylaşmıyor, aksine zorlaşmaktadır" ÖZTÜRK, Bahri, http:// www.abchukuk.com/haber/haber4829.html.15.11.2005.

${ }^{26}$ ÖZTÜRK, Bahri, http://www.abchukuk.com/haber/haber4829.html.15.11.2005. 
kişisel çıkar arasında bağlantının bulunması, ihlal olmasaydı kişisel çıkarın zedelenmiş olmayacağının ortaya konulması gerekmektedir ${ }^{27}$. Belirtmek gerekir ki mağdur olmak ile, mağdur olduğunu iddia etmek birbirinden farklı anlamlara sahiptir. Kişinin mağdur olup olmadığ 1 davanın esasının incelenmesi sonucunda anlaşılabilecektir. Kişinin mağdur olduğunu iddia etmesi ise bireysel başvurunun kabul edilebilirlik aşamasında önem taşımaktadır. Eğer kişi mağdur sıfatını taşıyorsa, başvuru kabul edilebilir bulunacak ve daha sonra kişinin mağdur olup olmadığı ortaya konacaktır ${ }^{28}$. $\mathrm{Bu}$ değerlendirmede, ilk incelemede sözleşmenin ihlal edilmediği genel görüntüsünün çıkmış olması da başvurunun reddedilmesi sonucunu doğuracaktır ${ }^{29}$. Mahkeme önüne gelen başvuruların ilk bakışta gözle görülebilir, ciddi bir Sözleşme ihlalinin mevcut olmasını arayacaktır ${ }^{30}$

Strasbourg Organlarının kararlarında mağdur ${ }^{31}$ kavramı geniş yorumlanmaktadır. Mağdur kavramı için gerekli şartlardan birisi de mağduriyetin gerçek, doğmuş, somut ve güncel olmasıdır ${ }^{32}$. Dolayısıyla başvuruda bulunan kişinin ileri sürdüğü insan hakkı ihlalinin gerçek mağduru olması ve bu nedenle de korunan bir hukuki yarara sahip olması gerekir ${ }^{33}$. Ayrıca Sözleşme organları, doğrudan mağdur yanında, potansiyel mağdur ve dolaylı mağdur kavramlarını da kabul etmektedir ${ }^{34}$. Mahkeme ve komisyonun mağdur kavramına özerk yorum yoluyla çok geniş anlamlar vermeleri sonucunda bireysel başvuru hakkı genişletilmiştirir ${ }^{35}$.

Yeni getirilen düzenlemenin nasıl anlaşılması gerektiği şüphesiz, Mahkeme'nin vereceği kararlarla ortaya konacaktır. Ancak yapılan bu düzenlemenin, hak ihlali ile ilgisi olmayan başvuruların eskiden olduğu gibi baştan itibaren kabul edilmeyeceği, ihlal durumlarında ise bunun önemli bir ihlal olması aranacaktır. Hiç şüphesiz düzenleme de yer alan "insan haklarına saygı ilkesi gereğince başvurunun esası hakkında incelemeye gerek bulunması" ve "başvuruya konu olayın iç hukuk mahkemesince yeterince incelenmemiş olması" durumunda bu kriter geçerli olmayacaktır. Söz konusu değişiklikler birlikte değerlendirildiğinde, getirilen bu

${ }^{27}$ MADRA, Ömer, Avrupa İnsan Hakları Sözleşmesi ve Bireysel Başvuru Yolu, Ankara 1981, s. 149- 150.

${ }^{28}$ ANAYURT, Ömer, Avrupa İnsan Hakları Hukukunda Kişisel Başvuru Yolu, Ankara 2004, s. $175-176$.

29 TEZCAN, Durmuş- ERDEM, Mustafa Ruhan- SANCAKDAR, Oğuz, Avrupa İnsan Hakları Sözleşmesi ve Uygulaması, Ankara 2004, s. 93.

${ }^{30}$ ANAYURT, s. 242.

31 "Mağdur sözcüğü, bir zarar bulunmasa bile bir ihlalin varlığının söz konusu olabileceği bir eylem veya işlemden doğrudan etkilenen kişiyi ifade etmektedir" Corigliano/ İtalya, Başvuru No: 8304/78, 10.12.1982. Aynı yönde, Dejon, Baljet ve Van Den Brink/Hollanda, Başvuru No: 8805/79, 22.05.1984.

${ }^{32}$ ANAYURT, s. 177.

33 TEZCANERDEM- SANCAKDAR, s. 33.

${ }^{34}$ ANAYURT, s. 177; ÖZDEK, s. 54; BOZKURT, Enver, İnsan Haklarının Korunmasında Uluslar arası Hukukun Rolü, Ankara 2003, s. 229.

${ }^{35}$ KABOĞLU, İbrahim, Anayasa Hukuku Dersleri, İ́stanbul 2005, s. 266. 
hükümlerle, iç hukukta alınan önlemlerle ve yapılan başvurularla giderilemeyen insan hakkı ihlalleri Avrupa İnsan Hakları Sözleşmesi çerçevesinde çözüme kavuşturulacaktır ${ }^{36}$. Sözleşme açısından temel bir soruna ilişkin olmayan başvuruların ayrıntılı olarak incelenmeden ilk aşamada kabul edilemez bulunacaktır. Dolayısıyla hak ihlallerinde önemli bir ihlal yani gerçek mağdurluk aranacaktır.

Şüphesiz bu ölçütün getirilmesi, Mahkeme'nin her geçen gün artan dava yükü karşısında gerekli görülmüştür. Önüne gelen başvuruların elenmesi sırasında, yardımcı olacak bu ölçüt sayesinde Mahkeme, esasa dair titiz bir inceleme gerektiren davalara daha çok zaman ayırabilecektir ${ }^{37}$. Kimi zaman son derece basit ve gereksiz konularda Mahkeme'ye müracaatta bulunulduğu görülmektedir. Kimi zaman da Sözleşme ile koruma altına alınmayan haklarla ilgili Mahkeme'ye müracaatta bulunulmaktadır ${ }^{38}$. Böyle bir düzenleme ile de bu ve bunun gibi başvuruların ilk incelemede elenmesi, önemli başvuruların titizlikle üzerinde durulmasının amaçlandı̆̆ını söyleyebiliriz ${ }^{39}$.

${ }^{36}$ Bakanlar Komitesi 7 Subat 2001 tarihinde almıs olduğu bir kararla Mahkemenin etkinliğini güvence altına alacak olası yolların incelenmesi için bir Değerlendirme Grubu oluşturdu. Değerlendirme Grubu hazırlamış olduğu raporunu 28.9.2001 tarihinde Bakanlar Komitesi’ne sundu. Bu raporda, bir takım çözüm önerlerine yer verilmiştir. Önerilen çözüm yolları arasında, bazı vakalarda, özellikle de özellikle de etkili iç hukuk yollarından yararlanılmadığ 1 durumlarda, başvuruların yeniden incelenmesi için ulusal yargı yerlerine gönderilmesini sağlayacak ek bir protokolün hazırlanması vardır. Bu öneri çerçevesinde, Sözleşmenin 35. maddesinde düzenlenen kabul edilebilirlik şartlarında da yeni bir düzenlemeye gidilmesi de düșünülmekteydi. Buna göre, Sözleşme açısından temel bir soruna ilişkin olmayan başvuruların ayrıntılı olarak incelenmeden ilk aşamada kabul edilemez bulunması ve bu başvurunun yeniden incelenmesi için ulusal makamlara geri gönderilmesi. ÇAVUŞOĞLU, Naz, İnsan Hakları Mahkemesi: Kararların Uygulanması, Türkiye Kararları, İstanbul 2003, s. 13- 14.

${ }^{37}$ Mahkeme Başkanı Luzius Wildhaber Anayasa Mahkemesi'ndeki konuşmasında bu durumu şu şekilde ifade etmiştir: "Sözleşmenin gerçek amacı Sözleşmeci Devletlerdeki temel hak ve özgürlüklerin korunmasındaki standartları yükseltmektir. Mümkün olduğu kadar çok sayıda Avrupa vatandaşının bireysel rahatsızlıklarına çözüm aramak yerine, vatandaşların kendi iç sisteminden yardım alabileceği bütün Avrupa'da geçerli temel haklar anayasal düzeninin kurulması konusunda gayretlerimizi yoğunlaştırmalıyız. Yine bu noktada, dolaylı olarak da olsa, ulusal sistemlerde uygun güvencelerin sağlanması gereksinimi ve özellikle ciddi insan hakları ihlallerinde etkin soruşturmaların yapılması ve ulusal mahkemelerin Sözleşmenin içtihat hukukunu uygulamaları gerektiği temalarına yine dönmüşs oluyorum". WILDHABER, Luzius, "Avrupa İnsan Hakları Mahkemesi Baskanı Luzius Wildhaber'in 25 Nisan Günü Ankara'da Anayasa Mahkemesi'ndeki Konuşması”, (Çev. Mehmet Turhan), Anayasa Yargis117, Ankara 2000, s.30-31.

${ }^{38}$ ANAYURT, s. 346.

${ }^{39}$ SIMMONS, s. 30; Bakır ÇAĞLAR her davanın AİHM'ne taşınmasını "Türk avukatlarının hukuksal şizofrenisi" olarak değerlenmektedir. ÇAĞLAR'a göre "Popstar, Türkstar kuyruğuna girenlerle, bugün AİHM'ye başvurmak için kuyruğa girenler arasında kesin bir paralellik bulunuyor. Bu pop kültürün hukuk versiyonudur" değerlendirmesinde bulunmaktadır. Milliyet Gazetesi, 11.03.2004; AİHM Yargıcı Rıza TÜRMEN de, Türklerin AİHM'yi temyiz mahkemesi gibi kullandığını, davaların 3 yıldan önce sonuçlanmadığını söyledi. Sözleşmeye taraf ülkelerin değişmesiyle, davaların niteliğinin de değişmeye başladığını ifade eden TÜRMEN, mahkemenin yetkilerini genişletmek, farklılaşan davalara göre yeni yapılanma içine girmek istediğini ifade etmektedir. Milliyet Gazetesi, 11.03.2004; Eski AİHM yargıçlarından Feyyaz GÖLCÜKLÜ de İnsanların "evimin 
Belirtmek gerekir ki, Mahkeme'nin sayısal olarak çok fazla başvuruyla meşgul olmak mecburiyetinde bırakılması, kararlarının düzeyinin korunmaması tehlikesini de beraberinde getirir. Bu durum ise Mahkeme'nin yönlendirici işlev görmesini engelleyecek ortamı hazırlayabilir ${ }^{40}$.

\section{7- Üçüncü Tarafın Müdahalesi}

Sözleşmenin 36. maddesi üçüncü $\operatorname{taraf}^{41}$ davaya müdahalesini düzenlemektedir. Bu maddeye göre, "Daire ve Büyük Daire önündeki tüm davalarda, vatandaşlarından birinin başvuran taraf olması halinde, Yüksek Sözleşmeci Tarafın yazılı görüş sunma ve duruşmalarda bulunma hakkı vardır. Mahkeme Başkanı, adaletin doğru sağlanabilmesi amacıyla, yargılamada taraf olmayan herhangi bir Yüksek Sözleşmeci Tarafı yazılı görüş sunma veya duruşmalarda taraf olmaya davet edebilir.

$\mathrm{Bu}$ maddeye eklenen 3. fikra ile Avrupa Konseyi İnsan Hakları Komiserinin, daireler veya büyük dairede görülen davalar hakkında yazılı görüş verebilmesi ve duruşmalara katılabilmesi hükmü getirilmiştir (14 Nolu Protokol md. 13).

İçtüzüğün 61. maddesine göre, "Bir başvurunun kabul edilebilirliğine dair verilen karar, Yazı İşleri Müdürü tarafından davadaki başvurucunun vatandaşı olduğu Sözleşmeci Devlet ile birlikte, İçtüzüğün 56.maddesinin ikinci fıkrasına göre davalı Sözleşmeci Devlete tebliğ edilir. Bir Sözleşmeci Devletin, Sözleşme'nin 36.maddesinin birinci fıkrası gereğince yazılı görüş sunmak veya duruşmada yer almak istemesi halinde, Daire Başkanı izlenecek usulü tayin eder. Daire Başkanı, adaletin gereği gibi yerine

penceresi kırıldı, devlet yaptırmadı" diye mahkemeye müracaatta bulunduğunu bu tür başvuruların kabul edilemeyeceğini, ama insanların iç hukukta kazanamayacağı davayı Avrupa İnsan hakları Mahkemesinde kazanacağını düşündüklerini, böyle bir şeyin mümkün olmayacağını ifade etmektedir. GÖLCÜKLÜ," "geçmişte mahkemenin reddi gereken davaları kabul ettiğini bu durumun insanları heyecanlandırdığını, AİHM, sözleşmedeki şartları titizlikle uygulasaydı davaların yarısını tasfiye etmiş olurdu" görüşlerine yer vermiştir. http://www.habervitrini. com/haber.asp?id=121890.(5.12.2005); AKILLLIOĞLU iç hukukta aradığını bulamayan herkesi Avrupa İnsan Hakları Mahkemesi'ne başvurduğunu belirtmektedir: "1987'den bu yana Avrupa Konseyi bağlamında Avrupa İnsan Hakları Sözleşmesi'nin yargı denetimi içinde yer aldığımızdan çoğu zaman yargı kararı aleyhine tecelli eden veya aradığını yargı kararında bulamayan herkes Avrupa Insan Hakları Mahkemesi'ne başvurmaktadır. Aslında bu bize özgü bir davranış biçim değildir. Yaygındır. Her ülkede kendini mağdur hisseden insanlar Strasbourg'a dilekçe göndermektedir. Doğrusu iç hukuklarda eğitim faaliyetlerini hızlandırarak hangi konularda Strasbourg'a gidilebileceği anlatılmalı/öğretilmelidir. Bundan önce iç hukukta yargıçlarımızın ikna edici kararlar vermesi de beklenmelidir" AKILLIOĞLU, Tekin, "İnsan Hakları Sorunu Deyimimin Anlamı ve İşlevi", http://www.egm.gov.tr/ apk/dergi/42/ makale/Tekin_AKILLIOGLU.htm.15.11.2005.

${ }^{40}$ YILDIZ, Mustafa, Avrupa İnsan Hakları Mahkemesi Yargısı, İstanbul 1998, s. 198.

41 İçtüzüğün 1. maddesinin $\mathrm{m}$ bendine göre, "üçüncü taraf" deyimi, Sözleşme'nin 36.maddesinin birinci ve ikinci fikralarında belirtilen ve bir duruşmada yer alma hakkını kullanan veya yazılı mütalaa vermesi veya duruşmaya katılması istenen bir Sözleşmeci Devleti veya ilgili kimseyi" ifade etmektedir. 
getirilmesi amacıyla, Sözleşme'nin 36.maddesinin ikinci fıkrasına göre davaya taraf olmayan bir Sözleşmeci Devleti veya başvurucu olmayan herhangi bir kimseyi yazılı görüş sunmaya veya istisnai hallerde duruşmaya katılmaya davet edebilir veya bunlara izin verebilir. Bu konudaki izinler, resmi dillerden birinde ve usulüne göre gerekçeli olarak, izlenecek yazılı usulün tayin edilmesinden sonra, makul bir süre içinde istenebilir. $\mathrm{Bu}$ maddenin üçüncü fıkrasına göre yapılan bir davet veya verilen bir izin, Daire Başkanı tarafından zaman sınırı da dahil çeşitli koşullara tabi tutulabilir. Bu koşulların yerine getirilmemesi halinde Başkan, sunulan görüşlerin dosyaya girmemesine karar verebilir".

\section{8- Davanın incelenmesi}

Sözleşme'nin 38. maddesinde yapılan değişiklikle, Mahkeme, başvuruyu tarafların temsilcileriyle birlikte inceler ve gerekirse, ilgili Yüksek Âkit Tarafların, etkin olarak yürütülmesi için gerekli tüm kolaylıkları sağlayacakları bir soruşturma yapar hükmü getirilmiştir (14 Nolu Protokol md. 14).

Davanın incelenmesi aşamasında, olayların tespiti konusunda, Mahkeme geniş yetkilere sahiptir ${ }^{42}$. Sözleşmenin 38. maddesine göre, "Mahkeme, kendisine gelen başvuruyu kabul edilebilir bulduğu takdirde, olayları saptamak amacıyla, tarafların temsilcileriyle birlikte başvuruyu incelemeye devam eder ve gerekirse, ilgili Devletlerin, etkinliği için gerekli tüm kolaylıkları sağlayacakları bir soruşturma yapacaktır”. Bu incelemede Mahkeme sadece dava hakkındaki gerekçeleri ve fiili durumları değil, olayın hukuki yönlerini de inceleyecektir. İnceleme taraflardan yazılı bilgi ve delil istenmesiyle başlar ve daha sonra taraflar sözlü açıklama yapmak üzere duruşmaya davet edilebiliir ${ }^{43}$. Duruşma sırasında, Daire üyelerinden biri de taraflara soru yönetebilir. Taraflar da başkanın izniyle, tanık ve bilirkişilere sorular yöneltebilir (İçtüzük md. 68).

Avrupa İnsan Hakları Mahkemesi görevi ilgili konularda yapılan başvuruları değerlendirirken Mahkeme İç Tüzüğünün 39. maddesine göre yürütmeyi durdurma (tedbir) kararı verebilir ${ }^{44}$. Bu maddeye göre, "Daire veya gerekiyorsa Daire Başkanı, bir tarafın veya ilgili herhangi bir kişinin talebi üzerine veya doğrudan kendisi, tarafların menfaati veya önündeki davanın gereği gibi görülebilmesi için alınması gerektiğini düşündüğü geçici tedbirleri taraflara bildirebilir. Bu tedbirlere ilişkin bildirimler, Bakanlar Komitesi'ne verilir. Daire, bildirdiği bir geçici tedbirin uygulanmasıyla bağlantılı bir konu hakkında taraflardan bilgi isteyebilir".

${ }^{42}$ BOZKURT, Enver- KANAT, Selim, Avrupa İnsan Hakları Sözleşmesi ve Avrupa İnsan Hakları Mahkemesine Başvuru Elkitab1, Ankara 2004, s. 69.

${ }^{43}$ ÜNAL, Seref, Avrupa İnsan Hakları Sözleşmesi, Ankara 2001, s. 398- 399.

44 TEZCAN, Durmuş, Avrupa İnsan Hakları Yargısı ve Türkiye İle İlgili Kararlar, http://www.inhak-bb.adalet.gov.tr/diger.htm.29.11.2005. 


\section{9- Dostane Çözümler}

Yeni yapılan düzenleme ile dostane çözüm ayrı bir maddede yeniden düzenlenmiştir. Sözleşmenin 39. maddesi dostane çözümler başlığını taşımaktadır. Bu maddeye göre, başvurunun herhangi bir aşamasında Mahkeme, Sözleşme ve Protokollerinde tanımlanan insan haklarına saygı esasından hareketle, davanın dostane çözüm ile sonuçlandırılması için ilgili taraflara hizmet sunabilir. Dostane çözüme ilişkin yürütülen işlemler gizlidir. Yürütülen işlemler sonucunda dostane çözüme ulaşılırsa, Mahkeme olaylarla ve varılan çözümle sınırlı kısa açıklamayı içeren bir karar vasıtası ile başvuruyu kayıttan düşürür. Bu karar, kararda belirtilen dostane çözüm şartlarının icrasını denetleyecek olan Bakanlar Komitesine iletilir. Yeni düzenlemeye göre, başvurunun her aşamasında dostane çözüm yoluna gidilebilecektir (14 Nolu Protokol md. 15). Bu Protokol öncesi düzenlemeye göre, dostane çözüm yoluna sadece başvurunun kabul edilmesinden sonra ancak davanın esasına geçilmeden önceki bir süreçte gidilebilmekteydi. Yapılan yeni düzenleme ile Mahkeme'ye yapılan başvuruların tekrar iç hukuka aktarılma amacının olduğunu söyleyebiliriz ${ }^{45}$. Çünkü, bilindiği gibi, Sözleşmenin getirdiği koruma ikincil nitelikte bir korumadır. İlgili Devletin başvurucunun hak ihlali olduğu yönündeki taleplerini, herhangi bir karar olmaksızın, çözme yönündeki karar ve istekliliği dostça çözüm sürecinin başarılı olmasında etkili olacaktır. Yapılan düzenleme ile başvurunun her aşamasında ilgili Devlet tarafından gösterilecek olumlu girişimler, hem hak ihlallerinin iç hukukta çözümlenmesine katkı sağlayacak hem de Mahkeme'nin önündeki iş yükünü azaltacaktır. Ayrıca, dostça çözümün, adaletin gecikmesini önlemek ve davanın sonucuna ilişkin belirsizliği önlemek gibi faydaları da vardır ${ }^{46}$. Yeni yapılan düzenlemenin bu olumlu yönüne rağmen, başvurunun her aşamasında dostça çözüme gidilebilecek olması, hakkında başvuruda bulunulan Devletleri, Mahkeme kararının etkisinden kurtulmak için bu yola sevk edebilecektir. Özellikle de başvurunun aleyhine sonuçlanacağını düşünen Devletler karardan çok kısa bir süre önce bu yola gidebilecek ve Sözleşme ihlali ve bunun sonuçlarından kurtulabilecektir ${ }^{47}$.

${ }^{45}$ ÇAVUŞOĞLU, İnsan Hakları Avrupa Mahkemesi, s. 73- 74.

${ }^{46}$ SIMMONS, s. 56.

${ }^{47}$ ÖZDEK, dostça çözümün çeşitli yönlerden eleştiriye açık olduğunu belirmektedir: "Sözleşmenin tanıdığı önemli bir yol olan dostça çözüm çeşitli yönlerden eleştiriye açıktır: Her şeyden önce, insan hakları ihlalleri gibi kamuyu ilgilendiren iddialarla AİHM önüne getirilen bir başvurunun, iki taraf arasındaki özel ve gizli görüşmeler sonucunda düşürülmesi kabul edilebilir bir yol değildir. Bașlı bașına boyla bir yolun tanınmıș olması, kamu düzenine ilişkin bir belge olan ve devletlerin ihlallerden sorumluluğunu sağlamak amacıyla hazırlanmış olan Sözleşmenin etkinliğini azaltmakta, devletlerin işledikleri ihlallerin ortaya çıkarılarak mahkûm edilmekten kurtulmalarına yol açmaktadır. Ayrıca, dostça çözüm görüşmelerinin gizliliği, Sözleşme sisteminin saydamlığını tartışmalı hale getirmektedir. Dostça çözüm kararında yalnız olayların ve ulaşılan sonucun kısa bir özeti yer aldığından, bu karardan dava süreci hakkında ayrıntılı bilgi edinmek de mümkün değildir. Uygulamada genellikle tazminat karşılığında dostça çözüme ulaşılmasını ise, ihlallerin para ile ölçülebilir bir bedeli olduğu anlayışına dayanması nedeniyle, insan 
Belirtmek gerekir ki, bir başvurunun dostça çözüm ile sonuçlandırılması için, yalnız taraflar arasında varılan bir uzlaşma yeterli değildir. Taraflar arasında varılan uzlaşmanın, Sözleşme ve Protokollerinde tanımlanan insan haklarına saygı şartlarına da uygun olması gerekir. Bu konuda takdir yetkisi Mahkeme'ye aittir. Mahkeme bu takdir yetkisini insan haklarına sayg 1 çerçevesinde belirleyecektir. Eğer taraflar arasından varılan uzlaşma insan haklarına saygı şartına uygun değilse, Mahkeme dostça çözüm kararı da vermeyebilecektir $^{48}$. Aynı şekilde başvurucunun ilgili Devletle uzlaşma sağlayamaması durumunda insan haklarına saygı çerçevesinde Mahkeme'nin dostça çözümü kabul edebileceğini söylemek mümkündür. Nitekim Mahkeme Akman/Türkiye davasında, başvuranın hükümetle dostça çözüm konusunda anlaşmamış olmasına rağmen, hükümetin başvurucuya tazminat ödeme teklifini ve gelecekte benzer ihlallerin yaşanmaması için tüm gerekli önlemleri alma taahhüdünü içeren tek taraflı talebini kabul etmiş ve incelemeye devam edilmesinde artık haklı bir gerekçe bulunmadığından başvurunun kayıttan silinmesine karar vermiştir ${ }^{49}$.

Taraflar arasında varılan ve Mahkeme tarafından benimsenmiş olan veya Mahkeme ile taraflar arasında birlikte yürütülen görüşmeler sonucunda varılan sonuç Mahkeme tarafından, başvurunun taraflarını, olay ve ulaşılan çözümü ve alınacak önlemleri kısaca içerecek biçimde karar haline getirilerek başvurunun kayıttan düşürülmesi sağlanmaktadır (AİHS md. 39; İçtüzük, md. 62$)^{50}$.

Dostça çözümün konusu, başvuran kişinin iç hukuktaki davasından vazgeçmesi şeklinde olabileceği gibi, sözleşmeci devletin, Sözleşmeye aykırı iç hukuk kuralını Sözleşmeye uygun hale getireceği taahhüdünde bulunması veya başvuran kişinin durumunu eski hale getirme şeklinde veyahut da belirli bir miktar tazminat ödenmesi şeklinde olabilir ${ }^{51}$.

Getirilen yeni bir değişiklikte, başvurunun dostane çözümle sonuçlanması ve bu durumun Mahkemenin kararıyla teyit edilmesi sonrasında bu kararın da denetlenmek üzere Bakanlar Komitesine gönderilmesidir (14 Nolu Protokol md. 15). Şüphesiz, bu değişiklik dostane çözüm şartlarının icrasını denetleyecek olan Bakanlar Komitesinin görevinin bir parçasıdır.

haklarının etiği ile bağdaştırmak güçtür” ÖZDEK, s. 67.

${ }^{48}$ ÖZDEK, s. 65- 66.

49 ÇAVUŞOĞLU, İnsan Hakları Avrupa Mahkemesi, s. 74. Akman/Türkiye, Başvuru no. 37453/97, 26.06.2001

${ }^{50}$ ANAYURT, s. 277

${ }^{51}$ YILDIRIM, Kadir, "Sözleşmenin ve Divan Kararlarının Uygulanma Niteliğì", Anayasa Yargis117, Ankara 2000, s. 324. 


\section{0- Kararların Bağlayıcılı̆̆ı ve Uygulanması}

Sözleşmenin kararların bağlayıcılığı ve uygulanması ile 46. maddesinde, Mahkeme'nin kararlarının kesin ve bağlayıcı olduğu, Mahkeme'nin kesinleşmiş kararlarının uygulanmasını denetleyecek olan Bakanlar Komitesine gönderileceği düzenlenmiştir. Bu maddeye kararların uygulanması ile ilgili yeni hükümler eklenmiştir. Buna göre, Bakanlar Komitesi kesin kararın icrasının denetlenmesinin kararın yorumlanmasına dair bir mesele tarafından engellendiği görüşünde ise, konuyu yorum meselesi hakkında bir hüküm vermesi için Mahkeme'ye gönderebilir. Gönderme kararının, Komiteye katılmaya yetkili temsilcilerin üçte iki çoğunluğuyla verilmesi gerekir (14 Nolu Protokol md. 16). Bakanlar Komitesi bir sözleșmeci tarafın, taraf olduğu davada verilen kesin karara uymayı reddettiği görüşünde ise, ilgili tarafa resmi bir ihbar tebliğ ettikten sonra ve Komiteye katılmaya yetkili temsilcilerin üçte iki oy çokluğuyla aldıkları kararla, ilgili tarafın karara uyup uymadığ 1 meselesini Mahkemeye intikal ettirebilir (14 Nolu Protokol md. 16). Mahkeme, ilgili devletin verilen karara uymadığını tespit ederse, alınacak önlemleri değerlendirmesi için davayı Bakanlar Komitesine gönderir. Mahkeme ilgili devletin, böyle bir ihlalini tespit etmezse, davayı, davanın incelenmesini bitirecek olan Bakanlar Komitesine gönderir (14 Nolu Protokol md.16). Mahkeme kararlarının etkin bir şekilde yerine getirilmesini öngören bu değişiklikle, ilk olarak kararın yerine getirilmesinin, kararın yorumlanmasına dair bir mesele tarafından engellendiği görüşünde ise, Bakanlar Komitesi konuyu yorum meselesi hakkında bir hüküm vermesi için Mahkeme'ye gönderebilmesidir. Ayrıca yeni düzenlemeye göre, Bakanlar Komitesinin gönderme kararının Komite'ye katılmaya yetkili temsilcilerin üçte iki oy çoğunluğuyla verilmesi gerekir. Bu düzenleme ile Sözleşme ve protokollerinin yorumlanması ile ilgili hukuki meseleler üzerinde görüş isteme yetkisi, kararın yorumlanması ile ilgili mesele ile sınırlandırılmış ve çoğunlukla gönderme kararı yerine, üçte iki oy çoğunluğu getirmiştir. İkinci olarak, Bakanlar Komitesi, ilgili ülkenin kesin karara uymayı reddettiği görüşünde ise, üçte iki çoğunlukla alacağı bir kararla, ilgili tarafın karara uyup uymadığı meselesini Mahkemeye intikal ettirebilmesidir. Mahkeme, bu intikal işlemine ilgili ülkeye tebliğden sonra başvuracaktır. Mahkeme kararın yerine getirilmediği görüşünde ise, bu tespite ilişkin kararı ile birlikte alınacak önlemleri değerlendirmesi için davayı Bakanlar Komitesi'ne gönderir. Mahkeme kararın yerine getirildiği görüşünde ise, bu kararı da Bakanlar Komitesi'ne gönderir. Getirilen bu düzenleme, Mahkeme kararlarının yerine getirilmesi konusunda önemli bir düzenlemedir. Bu düzenleme ile kararların yerine getirilmesinde Mahkemenin devreye sokulduğunu görmekteyiz. Kararın yerine getirilip getirilmediğinin tespiti bakımından Bakanlar komitesinin tek 
başına kullandığı yetki konusunda, Mahkemenin de yetkili kılınması, bu konudaki siyasal tutumları da önleyecektir ${ }^{52}$.

Avrupa İnsan Hakları Mahkemesi kararları Sözleşmeye taraf Devletler açısından bağlayıcıdır. Sözleşmenin 46. maddesine göre, "Yüksek Sözleşmeci Taraflar, taraf oldukları davalarda Mahkemenin kesinleşmiş kararlarına uymayı taahhüt ederler". Mahkeme'nin vermiş olduğu kararlar, ulusal mahkeme kararlarını ortadan kaldıramaz, onları değiştiremez. Avrupa İnsan Hakları Mahkemesi'nin görevi bir temyiz mahkemesi gibi çalışmak değildir ${ }^{53}$ Mahkeme vermiş olduğu karar ile Sözleşmenin ihlal edildiğgini belirler. Sözleşmeci devletler Mahkeme kararlarının uygulanması için gereken tedbirleri almaları gerekir. Yani Sözleşmeye aykırıllı̆ $\breve{1}$ tespit edilen durumun ortadan kaldırılması, ilgili Devletin sorumluluğundadır. Devletin bu sorumluluğunu yerine getirip getirmediğinin denetimi ise Bakanlar Komitesi tarafından yapılmaktadır ${ }^{54}$. Sözleşmenin 46. maddesinde kararların nasıl yerine getirileceğine ilişkin bir düzenleme yoktur. Her sözleşmeci Devlet, kararın nasıl yerine getirileceğini, buna ilişkin biçim ve içeriğgi kendisi belirleyecektir ${ }^{55}$. İlgili Devlet ihlali sona erdirmek ve mümkün olduğunca ihlal öncesi durumu yeniden sağlayacak şekilde ihlalin sonuçlarını giderme yükümlülüğü altındadır ${ }^{56}$. Eğer Mahkeme ihlal tespit etmişse, ilgili Devlete düşen yükümlülük, öncelikle bu ihlali sona erdirmektir. İhlal sona erdirildikten sonra durumu mümkün olduğu kadar ihlal öncesindeki şekline kavuşturacak şekilde eski hale iade gerekir. Eski hale iade mümkün değilse, ilgili Devlet Mahkeme'nin ihlal tespit ettiği kararla bağdaşabilecek araçları kendisi seçebilecektir ${ }^{57}$. Mahkeme, kararların uygulanması bakımından, uyumsuzluk sorunu çözme araçlarının seçimini sözleşmeci Devletlere bırakmaktadır ${ }^{58}$.

Mahkeme kararlarının gereği gibi yerine getirilmemesi halinde Avrupa Konseyi Statüsünün 8. maddesi işletilebilecektir. Bu maddeye göre de, insan

${ }^{52}$ CENGİZ, Serkan, "14 Nolu Protokol İle Avrupa İnsan Hakları Sözleşmesi'ne Getirilecek Olan Değişiklikler" http://www.turkhukuksitesi.com/makale_185.htm. 03.12.2005.

53 ANDREOTTI, Onur, Ulusal Mevzuatın Bir Parçası Olarak Avrupa İnsan Hakları Sözleşmesi Avrupa Konseyi'ne Üye Ülkelerde İnsan Haklarına Saygının Gözetilmesi İçin Bir Kontrol Mekanizması Olarak Avrupa İnsan Hakları Mahkemesi, http://www.abgm.adalet.gov.tr.11.12.2005

${ }^{54}$ BIÇAK, Vahit, "Uluslararası İnsan Hakları Normlarını Yorum Organı Olarak Avrupa İnsan Hakları Mahkemesi ve Kararlarının Türk Hukukunun Gelişimine Katkısı”, Anayasa Yargis117, Ankara 2000, s. 110.

${ }^{55}$ ÜNAL, Şeref, "Avrupa İnsan Hakları Mahkemesi Kararlarının Türk İç Hukukuna Etkileri”, Anayasa Yargisı17, Ankara 2000, s. 63; BOZKURT, s. 241.

${ }^{56}$ ÇAVUŞOĞLU, İnsan Hakları Avrupa Mahkemesi, s. 35; DOĞRU, Osman, "İnsan Hakları Avrupa Mahkemesi Kararlarının İç Hukuklara Etkileri”, Anayasa Yargısı17, Ankara 2000, s. 195; TURHAN, Mehmet, Anayasal Devlet, Ankara 2004, s. 199.

57 ÇAVUŞOĞLU, Naz, İnsan Hakları Avrupa Sözleşmesi ve Avrupa Topluluk Hukuku'nda Temel Hak ve Hürriyetler Üzerine, Ankara 1994, s. 70; EREN, Abdurrahman, Özgürlüklerin Sınırlanmasında Demokratik Toplum Düzeninin Gerekleri, İstanbul 2004, s. 307.

${ }^{58}$ ARSLAN, Zühtü, Anayasa Teorisi, Ankara 2005, s. 221. 
haklarını ciddi biçimde ihlal eden taraf Devletin Konseyde temsil hakkı askıya alınabilir ya da Konsey üyeliği sona erdirilebilir ${ }^{59}$.

\section{1- İmza ve Onay}

Sözleşmeye katılma ve onaylanmasının düzenlendiği 59. maddeye eklenen ikinci fıkrayla, Avrupa Birliğinin de bu sözleşmeye katılabileceği düzenlenmiş̧tir (14 Nolu Protokol md. 17). 14 Nolu Protokolün 18. maddesine göre, Bu Protokol, Sözleşme'yi imzalamış olan Avrupa Konseyi üyesi devletlerin imzalarına açıktır. Bu devletler Sözleşme ile bağlanmaya ilişkin onaylarını, onay, kabul veya uygun bulma koşuluna bağlı olmaksızın atılan imza veya onay, kabul veya uygun bulma koşuluna bağlı olarak atılan ve sonrasında onay, kabul ve uygun bulma işlemlerinin yapıldı ğı imza. Onaylama, kabul veya uygun bulma belgeleri Avrupa Konseyi Genel Sekreteri'ne tevdi edilir.

Sözleşmenin 59. maddedeki bu değişikliğin Avrupa Birliği’nde yaşanan gelişmeler, özellikle de Avrupa Birliği Anayasası göz önüne alınarak yapıldığı belirtilmektedir. Yapılan bu değişikliğin Avrupa Birliği Anayasası'nda karşılı̆̆ı Anayasa'nın I-9/2 maddesinde, şu şekilde yer almıştır: "Birlik, İnsan Hakları Avrupa Sözleşmesi'ne katılabilir. Böyle bir katılım Birlik'in Anayasa'da tanımlanan yetkilerini etkilemez"60. Bu katılımla birlikte, Avrupa Birliği de Mahkeme önünde davalı olarak yargilanabilecektir.

14 Nolu Protokolün 20 maddesinde, Protokol'ün yürürlüğe girdiği tarihten itibaren hükümleri, Avrupa İnsan Hakları Mahkemesi'nde görülmekte olan bütün başvurular ile icrası Bakanlar Komitesi tarafından denetlenen bütün kararlara uygulanacağı belirtilmiştir. Bu Protokol'ün yeni kabul edilebilirlik şartı, Protokol'ün yürürlüğe girmesinden önce kabul edilebilir bulunmuş olan başvurulara uygulanmayacaktır. Ayrıca Bu Protokol'ün yürürlüğe girmesini müteakip iki yıl boyunca, yeni kabul edilebilirlik şartı sadece Mahkeme'nin Daireleri ve Büyük Dairesi tarafından uygulanabilecektir(14 Nolu Protokol md. 20). Başka bir ifadeyle tek yargıç oluşumunda ve komite önünde, her durumda yeni kabul edilebilirlik şartı uygulanacaktır ${ }^{61}$.

${ }^{59}$ ÇAĞLAR, Bakır, İnsan Hakları Avrupa Sözleşmesi Hukukunda Türkiye, Türkiye Bilimler Ákademisi Forumu 6, Ankara 2002, 27; Avrupa Konseyi Statüsü madde 8: “Avrupa Konseyi'nin üçüncü madde hükümlerini ciddi surette ihlal eden, her üyesi temsil hakkından bir müddet için mahrum edilebilir ve Bakanlar Komitesi tarafından yedinci maddedeki sartlar dahilinde Konsey’den çekilmeye davet edilebilir. Bu davet nazarı itibaren alınmadı $\breve{g}_{1}$ Komite, bizzat Komite'nin tayin edeceği tarihten itibaren bahis mevzuu üyenin artık Konseye mensup olmadı ğına karar verebilir."

60 ÇAVUŞOĞLU, Naz, Avrupa Birliği ve İnsan Hakları Avrupa Sözleşmesi: Katılım Meselesi, Anayasa Yargisı 22, Ankara 2005, s. 321.

${ }^{61}$ AYKAÇ, s. 87. 


\section{SONUÇ}

Uzun bir süredir varlığını devam ettiren Mahkemenin içtihatlarına bakıldığında, Avrupa İnsan Hakları Mahkemesi'nin tüm taraf ülkelerde, temel hak ve özgürlüklerin gelişmesinde kuşkusuz önemli payı olmuştur. Mahkeme'nin verdiği kararların bazıları eleştiri konusu yapılsa da, günümüzde uluslar arası hukukta, insan hakları alanında en etkili koruma mekanizmasına sahiptir. Mahkeme, verdiği kararları ve bu kararlarda belirtilen esaslar, Sözleşmeci Devletlerde geçerli olacak hukuki standartları yansıtmaktadır. Mahkeme'nin çeşitli kararlarında belirttiği gibi, bu mekanizmanın dayandı ̆̆ı Avrupa İnsan Hakları Sözleşmesi Avrupa'nın kamu düzenini temsil etmektedir. Mahkeme vermiş olduğu kararlarla Avrupa Ülkelerinde yaşayan insanların günlük yaşantılarına katkı sağladığı gibi, aynı zamanda tüm dünya için minimum adalet standartları koyma işlevini yerine getirmektedir ${ }^{62}$.

1 Kasım 1998 tarihinde yürürlüğg giren 11 Nolu Protokol ile, Komisyon ve Divan'dan oluşan iki aşamalı mahkeme ilga edilmiş ve yerine aleniyet ilkesinin geçerli olduğu, tam gün çalışan tek aşamalı mahkeme getirilmiştir. $\mathrm{Bu}$ protokolle mahkemenin yapısında ve denetim sisteminde önemli ölçüde değişiklikler yapılmıştır. Bu değişikliklerden sonra, Mahkemeye yapılan başvurularda ve Mahkeme'nin verdiği kararlarda önemli oranda bir artış görülmüştür. 11 Nolu Protokol hiç şüphesiz denetim mekanizmasını hızlandırmıştır. Mahkemeye artan oranda başvurunun yapılması, mahkemenin artan iş yükü ve Sözleşmeye taraf ülke sayısının artması karşısında, denetim mekanizmasında yeni bir değişiklik yapma ihtiyacı duyulmuştur.

Denetim mekanizmasının değiştirilmesine ilişkin 14 Nolu Protokol 13 Mayıs 2004 tarihinde sözleşmeye taraf Devletlerin imzasına açılmıştır. Protokol ile Sözleşmede bir takım değişiklikler öngörülmektedir. Tek yargıç düzeni, yargıçların görev süreleri, komitelerin yetkileri, kabul edilebilirlik şartları, dostane çözümler, davanın incelenmesi ve kararların bağlayıcılığı ve uygulanması ile ilgili konularda önemli değişiklikler yapılmaktadır. Yine bu değişikliklerle Mahkeme tarafından incelemeye değer bulunmayan, ancak büyük zaman kaybına yol açan önemsiz nitelikteki başvuruların ilk incelemelerinin daha hızlı yapılarak sonuçlandırılmasını, başvuruların daha az sayıda yargıç tarafından incelenebilmesi ve kabul edilebilirlik şartlarına başvuran kişinin önemli oranda zarar görmesi unsurunun eklenmesi öngörülmektedir. Yapılan bu değişiklikler denetim sistemini daha da etkinleştirmeye yöneliktir.

Tek yargıcın bir başvurunun kabul edilebilirliğine ilişkin karar verebilmesi ve komitelerin bir başvurunun esasını karara bağlama yetkisi,

${ }^{62}$ BIÇAK, Vahit, "Yeni Yapısıyla Avrupa İnsan Hakları Mahkemesi", http://www.geocities. com/vbicak/art2. htm.17.11.2005. 
Mahkeme'nin giderek artan iş yükünü önemli ölçüde hafifletecektir. Mahkeme'nin Avrupa'da insan haklarının korunması konusundaki üstün rolünü devam ettirebilmesi için bu tür değişikliklere ihtiyaç vardır. Bu tür değişiklikler, Mahkeme'nin karar sürecini de etkileyecektir. Mahkeme daha kısa bir sürede karar alabilecektir.

Ancak bu değişiklikler sonrasında başvuru sayısında ve mahkemenin yoğun iş yükünde belli bir azalma gözlenebilecek ise de, bu yapılanma da ulaş1lmak istenen çözümü yeterince sağlayamayacaktır. Çünkü başvuru sayısındaki ve karar sayısındaki artış bu mekanizmanın gittikçe yoğunlaşacağını göstermektedir. Sözleşmeci taraflar açısından iç hukuk yeterince etkinleştirilemezse, denetim mekanizması bu boşluğu dolduracaktır. Dolayısıyla yapılması gereken, Sözleşmenin ikincil niteliğini göz önünde bulundurarak, çözümün iç hukukta sağlanması olacaktır. Çünkü sözleşmenin iç hukuku tamamlayan bir özelliği vardır. 